\title{
PEMBUATAN ULTRA FINE AMORPHOUS SILICA (UFAS) DARI JERAMI DAN SEKAM PADI
}

\author{
I Wayan Karyasa \\ Jurusan Pendidikan Kimia, FMIPA \\ Universitas Pendidikan Ganesha \\ Singaraja, Indonesia \\ e-mail: karyasa.undiksha@gmail.com
}

\begin{abstract}
Abstrak
Penelitian ini bertujuan membuat UFAS dari jerami dan sekam padi dan mengkarakterisasi hasilnya dengan XRF dan XRD. Bubuk abu sekam dan jerami padi dihasilkan melalui leaching dan tanpa leaching. Abu dianalis dengan XRF, kemudian direfluks menjadi UFAS dan hasilnya dianalisis dengan XRD dan XRF. UFAS dari sekam padi dengan leaching menghasilkan randemen tertinggi, fase amorp dan tingkat kemurnian yang paling baik. Melalui leaching, abu jerami juga menghasilkan UFAS tetapi dengan randemen yang lebih rendah. UFAS yang dihasilkan diidentifikasi sebagai bubuk silika amorp dengan fase kristobalit.
\end{abstract}

Kata kunci: silika amorp, jerami dan sekam padi.

\begin{abstract}
This research is aimed to prepare UFAS using rice straws and husks and to characterize the products. Ashes of rice straws and husks were prepared through leaching and without leaching. The ashes were analyzed using XRF, and they were refluxed to produce $U$

FAS powders and analyzed using XRF and XRD. The results of the research showed that the UFAS prepared from rice husk with leaching produced high mass ratio product-starting material, better amorphous phase and the best purity. Rice straw with leaching could be used in preparing UFAS but having less mass ratio product-starting material. The resulted UFAS powders were identified as amorphous silica in phase of crystobalite.
\end{abstract}

Keywords: amorphous silica, rice straw, and rice husk.

\section{PENDAHULUAN}

Padi merupakan tanaman yang paling utama di sebagian besar belahan bumi karena beras merupakan salah satu makanan pokok. Produksi padi dunia diperkirakan sekitar 550.000.000 ton/tahun (Wada, et.al, 2005). Selain jerami, limbah utama pertanian padi adalah sekam padi yang diperkirakan sekitar 100.000.000 ton/tahun dan Thailand sendiri memproduksi sekam padi 4.000.000 ton/tahun (Wada, et.al, 2005). Sedangkan Indonesia menghasilkan sekam padi sekitar 13.000.000 ton/tahun (Balipost, 2003). Pemberian nilai tambah terhadap limbah sekam padi yang melimpah ini telah menjadi pusat perhatian banyak orang 
dengan beberapa alasan. Pertama, sekam padi merupakan material terbarukan sebagai alternatif penghasil energi hijau. Sekam padi tanpa pengolahan sebelumnya jika dibakar mampu menghasilkan panas sekitar $3.600 \mathrm{kcal} / \mathrm{kg}$ sedangkan batubara $6.000 \mathrm{kcal} / \mathrm{kg}$ (Wada, et.al, 2005). Kedua, sekam padi merupakan limbah pertanian yang kaya silikon dan jika dibakar mampu menghasilkan silika $\left(\mathrm{SiO}_{2}\right) 10$ - 15 \% b/b (Real, et.al, 1996; Conradt, et.al, 1992). Variasi prosentase silika yang dihasilkan dari pembakaran abu sekam berkaitan dengan tanah tempat tumbuhnya padi. Sekam padi yang diambil dari daerah Baturiti Tabanan menghasilkan silika 20,6\% b/b (Karyasa dan Walter, 2003). Silika yang dihasilkan dari abu sekam padi berupa bubuk putih dengan kemurnian 94-96 \% $\mathrm{b} / \mathrm{b}$ dengan pengotor $\mathrm{K}_{2} \mathrm{O}, \mathrm{Na}_{2} \mathrm{O}$ dan $\mathrm{Fe}_{2} \mathrm{O}_{3}$. Pengotor tersebut dapat dengan mudah dilarutkan dengan asam-asam mineral sehingga diperoleh silika amorp yang reaktif dengan kemurnian sampai 99 \% b/b (Real, et.al, 1996). Seperti yang telah di sampaikan di atas, selain sekam padi, limbah yang paling banyak dari pertanian padi adalah jerami. Akan tetapi, sampai saat ini pemanfaatan jerami masih sebatas untuk makanan ternak dan kompos. Para petani masih banyak membakar begitu saja jerami di atas lahan persawahannya langsung setelah panen. Jerami juga merupakan biomassa yang kaya silikon seperti halnya sekam padi sehingga jerami juga dapat dimanfaatkan sebagai penghasil silika jika dibakar.

Keunggulan silika yang berbahan baku limbah pertanian padi dibandingkan silika yang diperoleh dari deposit batuan (kuarsa) adalah (1) silika dari sekam padi memberi nilai tambah terhadap limbah pertanian, sedangkan silika dari batuan menyebabkan kerusakan lingkungan akibat penambangan deposit, (2) silika dari sekam padi amorp dan reaktif serta memerlukan tidak banyak energi kalau ditransformasi ke struktur kritobalit sehingga cocok untuk starting material dalam memproduksi senyawa turunannya, sedangkan silika dari batuan umumnya kristalin (tipe struktuir kuarsa) yang memerlukan banyak energi untuk menstransformasi ke struktur kristobalit dan amorp, dan (3) silika dari abu sekam padi langsung dapat berupa bubuk dengan kemurnian tinggi serta memurnikannya mudah sedangkan untuk mendapatkan silika bubuk murni dari batuan kuarsa memerlukan banyak energi untuk penggilingan dan pemurnian. Selain silika amorp, jerami dan sekam padi juga dapat menghasilkan (1) karbon aktif yang memiliki luas permukaan yang spesifik $1517 \mathrm{~m}^{2} / \mathrm{g}$ dan mempunyai kemampuan absorpsi yang baik terhadap fenol, logam-logam berat dan ammonia-nitrogen (Kim and Choi, 1998), (2) silikon karbida (Gorthy and Pudukotta, 1999; Karyasa and Walter, 2003), (3) silikon nitrida (Rahman and Riley, 1989), (4) logam silikon yang telah banyak dilaporkan orang untuk panel sel surya, polimer silikon, silikon semikonduktor dan chip silikon, dan (4) turunan silika seperti zeolit (Panpa, et.al, 2005), keramik mullit (Saiintawong, et. al, 2005) dan yang terbaru adalah silika aerogel (Halimaton, 2007).

Masih banyak lagi material-material baru lainnya yang dapat dibuat dari abu sekam padi dan turunannya untuk berbagai penggunaannya menunjang 
kemajuan ilmu pengetahuan dan teknologi.

Metode pembuatan silika murni yang amorp telah dikembangkan orang sejak tiga dekade terakhir. Tingkat keamorpan atau sebaliknya kristalinitas silika, ukuran partikel, luas permukaan, kereaktifan serta tingkat kemurnian silika yang dihasilkan merupakan parameter utama dalam mengukur keberhasilan pembuatan silika dari sekam padi. Faktor-faktor yang berpengaruh adalah suhu bakar, lama pembakaran dan pengolahan awal sebelum dibakar (Mehta, 1977; Copra, et.al, 1981; Ikram, et al.,1984; Yeoh, et al., 1979 dalam Nizami, 1993). Umumnya, semakin rendah suhu dan pembakaran semakin lama, tingkat keamorpan semakin baik. Perlakuan awal dapat memperbaiki kualitas kereaktifan, luas permukaan dan ukuran partikel. Sedangkan post-treatment yaitu pengolahan abu silika setelah pembakaran juga berpengaruh terhadap kualitas produk silika amorp yang dihasilkan (Halimaton, 2007; Thundaij and Nuntiya, 2008). Namun demikian, penelitian mereka dilakukan pada rentang suhu dan waktu bakar yang panjang (antara suhu bakar 300 $1300^{\circ} \mathrm{C}$ dan lama bakar 1 jam hingga dua minggu) serta metode pre dan post treatment yang sangat variatif sehingga belum padu menjadi satu paket yang utuh sesuai dengan tingkat kualitas silika yang perlu dihasilkan. Bahkan, bubuk silika murni dengan skala nano telah berhasil dibuat melalui metode pengendapan yang menggunakan bahan awal abu sekam padi yang dibuat tanpa pengolahan awal terhadap sekam padi yang digunakan (Thuadaij and Nuntiya, 2008). Selain metode pengendapan, metode sol-gel merupakan metode yang memungkinkan digunakan untuk memperoleh produk sintesis dengan skala nanometer (Schmidt, 2001).

Mengingat ketersediaan bahan baku jerami dan sekam padi yang melimpah di Indonesia maka pengembangan berbagai produk-produk material terbarukan berbahan baku tumbuhan tropis kaya silikon (siliconeous rich tropical plants) seperti limbah pertanian padi yang berupa jerami dan sekam memiliki prospek daya saing global yang tinggi. Salah satu material anorganik terbarukan yang strategis untuk dikembangkan adalah bubuk super halus silika amorp atau ultra fine amorphous silica (UFAS). Keistimewaan UFAS adalah (1) berupa bubuk amorp yang sangat halus dan reaktif sehingga sangat prospektif digunakan sebagai bahan awal (starting material) untuk pembuatan berbagai produk turunan yang unggul seperti (a) ultra fine amorphous colloidal silica (UFACS) yang sangat prospektif untuk material kedap suara dan isolasi panas (insulation) dan anti balistik, (b) wollastonite sintetik, suatu mineral kalsium metasilikat yang juga banyak dikembangkan untuk material anti balistik di samping sebagai bahan baku keramik, (c) zeolit sintetik maupun berbagai zeotype sintetik lainnya seperti silikofosfat dan alumniosilikofosfat; dan (2) bersifat meso sampai nanoporus yang kemungkinan besar dapat dimanfaatkan untuk menyerap nanopartikel, molekul dan bahkan radikal bebas.

Secara umum penelitian ini bertujuan untuk membuat bubuk ultra fine amorphous silica (UFAS) berbahan 
baku jerami dan sekam padi dan mengkarakterisasi UFAS yang dihasilkan. Secara khusus penelitian ini bertujuan menemukan metode pembuatan UFAS berbahan baku limbah pertanian padi dengan membandingkan karakter produk bubuk UFAS yang dihasilkan dari jerami dan sekam padi, baik dengan rute pembubukan bahan baku, pembakaran dan pemurnian maupun dengan rute pembubukan bahan baku, leaching dengan asam mineral, pembakaran dan pemurnian ditinjau dari fase amorp yang dianalisis dengan metode $X$-Ray Diffraction (XRD), dan tingkat kemurnian dengan X-Ray Fluorescence (XRF) dari bubuk UFAS yang dihasilkan.

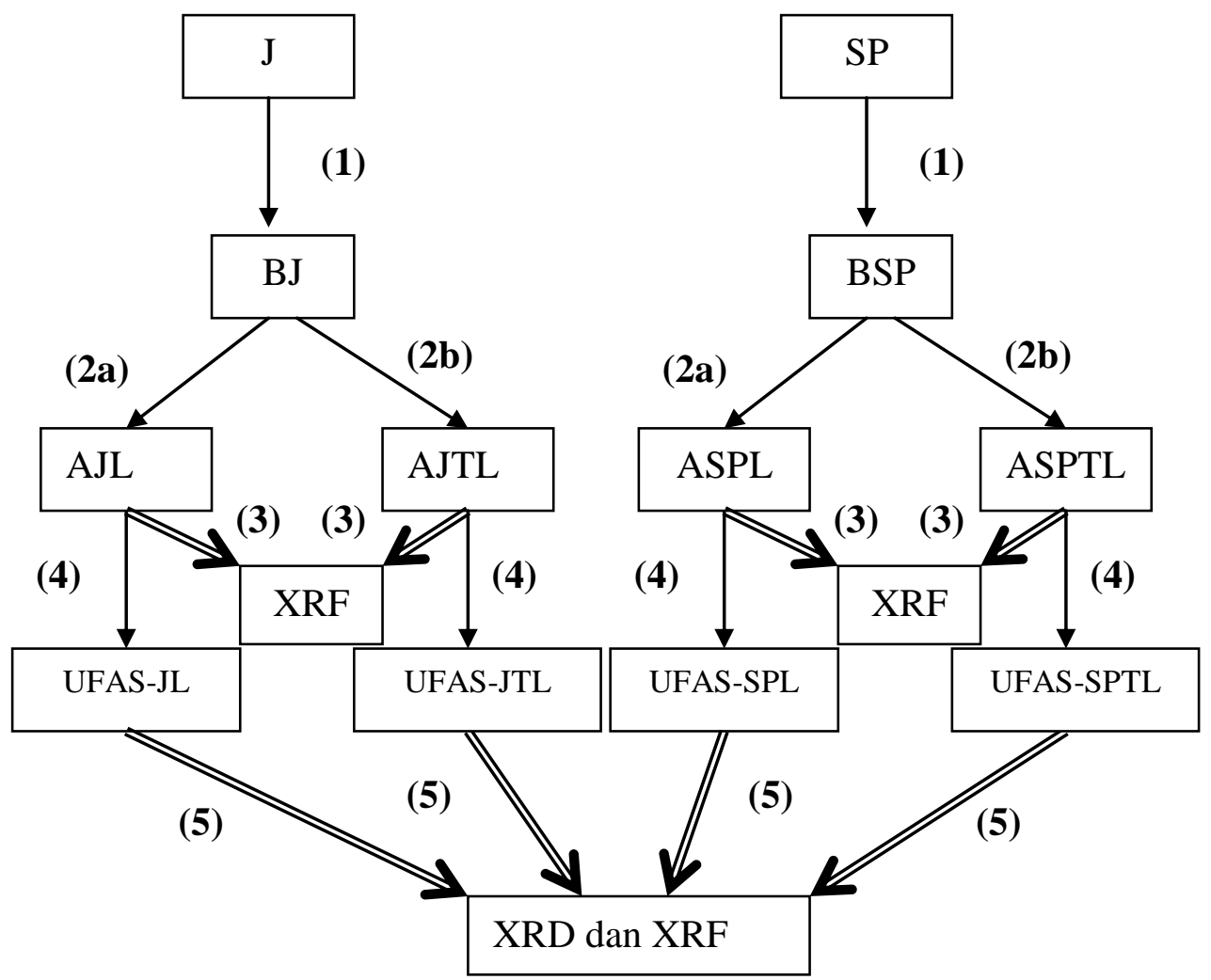

Gambar 1 Diagram Alir Penelitian
METODE

Penelitian ini merupakan penelitian pengembangan melalui eksperimen di laboratorium. Penelitian pengembangan yang dimaksud adalah pengembangan cara pembuatan bubuk ultra fine amorphous silica (UFAS) terbarukan berbahan baku limbah pertanian padi yaitu jerami dan sekam padi dengan memodifikasi berbagai metode yang dipublikasikan oleh para peneliti sebelumnya (Schmidt, 2001; Karyasa dan Walter, 2003; Halimaton, 2007; Thuadaij and Nuntiya, 2008). Rancangan penelitian disajikan dalam alur penelitian berikut. 
Keterangan:

$\mathrm{J}=$ jerami, $\mathrm{SP}=$ sekam padi, $\mathrm{BJ}=$ bubuk jerami, BSP = bubuk sekam padi, $A J L=a b u$ jerami melalui tahap leaching, $A J T L=a b u$ jerami tanpa melalui tahap leaching, ASPL = abu sekam padi melalui tahap leaching, ASPTL = abu sekam padi tanpa melalui tahap leaching, UFAS-JL = ultra fine amorphous silica berbahan baku jerami melalui tahap leaching, UFAS-JTL = ultra fine amorphous silica berbahan baku jerami tanpa melalui tahap leaching, UFAS-SPL = ultra fine amorphous silica berbahan baku sekam padi melalui tahap leaching, dan UFAS$\mathrm{SPTL}=$ ultra fine amorphous silica berbahan baku sekam padi tanpa melalui tahap leaching.

(1) = pencucian, pengeringan, pencincangan bahan baku dan pembubukan hingga lolos 80 mesh, (2a) = leaching dengan asam klorida 1 , M, 2 M dan 3 M berturut-turut terhadap bubuk jerami atau sekam padi lalu pembakaran berturut-turut $650^{\circ} \mathrm{C}$ dan $750^{\circ} \mathrm{C}$, (2b) pembakaran berturut-turut $650^{\circ} \mathrm{C}$ dan $750^{\circ} \mathrm{C}$ tanpa melalui leaching terlebih dahulu, (3) = pengukuran XRF untuk analisis tingkat kemurnian silika dan adanya pengotorpengotor, (4) = pemurnian, refluks, pengendapan, pengeringan dan kalsinasi, (5) = identifikasi fase amorp dengan XRD, dan analisis tingkat kemurnian UFAS dengan XRF.

Penelitian ini menggunkan sampel jerami dan sekam padi varietas IR 64 yang ditanam di Desa Kedewatan, Kecamatan Ubud, Kabupaten Gianyar dan diambil pada musim panen sekitar bulan Mei 2009. Sekam padi yang digunakan adalah sekam dari padi yang diperoleh dari petak sawah yang diambil jeraminya sebagai sampel. Langkah-langkah penelitian di laboratorium dapat diuraikan sebagai berikut.

(1) Pembuatan dan Silika Abu Jerami dan Abu Sekam Padi

Jerami dan sekam padi dibersihkan dari kotoran padat, dicuci dan dikeringkan. Jerami dan sekam padi yang kering lalu ditumbuk halus hingga lolos saringan 80 mesh. Sebagian bubuk jerami dan sekam padi di-leaching menggunakan larutan $\mathrm{HCl} 3$ $\mathrm{M}$ pada suhu kamar selama 1 jam lalu dicuci dengan aquades berkali-kali hingga air cucian netral $(\mathrm{pH}$ mendekati 7). Bubuk jerami (BJ) dan bubuk sekam padi (BSP) yang telah di-leaching kemudian dikeringkan dan dibakar pada furnace pada suhu $650^{\circ} \mathrm{C}$ selama 3 jam lalu pada suhu $750^{\circ} \mathrm{C}$ selama 3 jam sehingga diperoleh dua bubuk putih yang halus (kode AJL untuk abu jerami yang berasal dari jerami yang dileaching) dan kode ASPL untuk abu sekam padi yang berasal dari bubuk sekam padi yang di-leaching). Sebagian bubuk jerami dan sekam padi yang tidak di-leaching (JTL dan SPTL) dibakar pada furnace pada suhu $650^{\circ} \mathrm{C}$ selama 3 jam lalu pada suhu $750^{\circ} \mathrm{C}$ selama 3 jam untuk menghasilkan berturut-turut bubuk putih AJTL dan ASPTL. Semua bubuk putih yang dihasilkan (AJL, ASPL, AJTL dan ASPTL) dianalisis kandungan silika dan pengotor-pengotornya menggunakan XRF.

(2) Pembuatan bubuk UFAS

Keempat bubuk abu AJL, ASPL, AJTL dan ASPTL kemudian dicuci dengan $\mathrm{HCl}$ berturut-turut dengan konsentrasi $1 \mathrm{M}, 2 \mathrm{M}$ dan 3M untuk melarutkan oksida-oksida logam 
pengotor. Bubuk yang telah dicuci dengan $\mathrm{HCl}$ selanjutnya dicuci kembali dengan aquades hingga air cucian netral. Silika murni yang diperoleh direflux menggunakan larutan $\mathrm{HCl} 6 \mathrm{~N}$ selama 4 jam, kemudian dicuci dengan aquabides sampai bebas asam. Hasilnya dilarutkan dengan larutan $\mathrm{NaOH} 2,5 \mathrm{~N}$ dengan pengadukan kontinyu menggunakan magnetic stirrer selama 10 jam, kemudian ditambahkan $\mathrm{H}_{2} \mathrm{SO}_{4}$ pekat hingga $\mathrm{pH}$ berkisar 7,5-8,5 (Thundaij and Nuntiya, 2008). Endapan silika yang terbentuk dicuci dengan aquabides hangat sampai filtrat cucian bebas alkali. Selanjutnya, dicuci lagi dengan aquabides dingin dan dikeringkan dalam oven pada suhu $50^{\circ} \mathrm{C}$ selama 48 jam. Dengan demikian akan diperoleh ultra fine amorphous silica (UFAS) berturut-turut UFAS-JL, UFAS-SPL, UFAS-JTL, UFAS-SPTL. Keempat silika amorp ini dikarakterisasi dengan XRD dan XRF.

(3) Analisis, Identifikasi dan

Karakterisasi

Analisis kandungan silika dan oksida-oksida pengotor dari AJL, ASPJL, AJTL, dan ASPTL serta UFASJL, UFAS-SPL, UFAS-JTL, dan UFASSPTL menggunakan XRF. Indentifikasi fase dan struktur UFAS-JL, UFAS-SPL, UFAS-JTL, dan UFAS-SPTL menggunakan XRD. X-Ray diffraktometer yang menggunakan sinar monokromatik $\mathrm{Cu}$-Ka1 digunakan untuk mengidentifikasi fase-fase yang ada pada keempat sampel silika ultra fine tersebut. Laju scan yang digunakan adalah $10 /$ menit dengan $2 \theta=5^{\circ}-65^{\circ}$. Data penelitian ini berupa data kualitatif dan data kuantitatif. Data diolah dengan berbagai perhitungan, penyajian data dengan tabel dan gambar dan dianalisis secara deskriptif.

\section{HASIL DAN PEMBAHASAN}

Hasil preparasi UFAS berbahan baku jerami dan sekam padi dengan dan tanpa pre-treatment leaching berupa massa dan randemen untuk setiap langkah perlakuan dapat dijabarkan pada Tabel 1 di bawah ini.

UFAS berbahan baku sekam padi dengan leaching menghasilkan randemen tertinggi dibandingkan dengan UFAS sekam padi tanpa leaching dan UFAS berbahan baku jerami padi. Untuk sekam padi, pretreatment leaching mempengaruhi massa produk UFAS yang dihasilkan, hal ini berbeda dengan UFAS dari jerami padi. Namun, dilihat dari warna bubuk dan kehalusan bubuk yang dihasilkan, keempat UFAS dari sekam dan jerami padi sulit dibedakan, sehingga perlu dikarakterisasi dengan metode instrumentasi, yaitu XRD dan XRF.

Tabel 1. Massa dan Randemen Produk Hasil Perlakuan

\begin{tabular}{|c|c|c|c|c|}
\hline $\begin{array}{c}\text { Material/ } \\
\text { Sampel }\end{array}$ & $\begin{array}{c}\text { Massa } \\
\text { Sebelum }\end{array}$ & $\begin{array}{c}\text { Perlakuan } \\
(\mathrm{g})\end{array}$ & $\begin{array}{c}\text { Massa } \\
\text { Setelah } \\
\text { Perlakua } \\
\mathrm{n} \\
(\mathrm{g})\end{array}$ & $\begin{array}{c}\text { Randeme } \\
\mathrm{n}(\%)\end{array}$ \\
\hline Sekam padi & 200 & $\begin{array}{c}\text { leaching, pencucian serbuk } \\
\text { sekam dengan HCl 3M dan }\end{array}$ & 161 & 80,5 \\
\hline
\end{tabular}




\begin{tabular}{|c|c|c|c|c|}
\hline & & $\begin{array}{l}\text { kemudian dikeringkan untuk } \\
\text { menghasilkan bubuk sekam } \\
\text { padi. }\end{array}$ & & \\
\hline Jerami & 200 & sda & 117 & 58,5 \\
\hline $\begin{array}{l}\text { Bubuk } \\
\text { sekam } \\
\text { leaching } \\
\text { (SPL) }\end{array}$ & 100 & $\begin{array}{l}\text { dibakar dengan furnace pada } \\
\text { suhu berturut-turut } 650 \text { dan } \\
750 \text { derajat Celcius masing- } \\
\text { masing selama } 3 \text { jam menjadi } \\
\text { abu sekam }\end{array}$ & 25,0154 & 25,0154 \\
\hline $\begin{array}{l}\text { Bubuk } \\
\text { sekam tanpa } \\
\text { leaching } \\
\text { (SPTL) }\end{array}$ & 100 & sda & 18,3112 & 18,3112 \\
\hline $\begin{array}{l}\text { Bubuk jerami } \\
\text { leaching (JL) }\end{array}$ & 100 & sda & 22,4362 & 22,4362 \\
\hline $\begin{array}{l}\text { Bubuk jerami } \\
\text { tanpa } \\
\text { leaching } \\
\text { (JTL) }\end{array}$ & 100 & sda & 18,8012 & 18,8012 \\
\hline $\begin{array}{l}\text { Abu sekam } \\
\text { padi leaching } \\
\text { (ASPL) }\end{array}$ & 25,0154 & $\begin{array}{l}\text { pencucian, refluk dan } \\
\text { pengeringan untuk } \\
\text { mendapatkan UFAS }\end{array}$ & 6,2598 & 25,0238 \\
\hline $\begin{array}{l}\text { Abu sekam } \\
\text { padi tanpa } \\
\text { leaching } \\
\text { (ASPTL) }\end{array}$ & 18,3112 & sda & 5,4778 & 29,9150 \\
\hline $\begin{array}{l}\text { Abu jerami } \\
\text { leaching } \\
\text { (AJL) }\end{array}$ & 22,4362 & sda & 5,7621 & 25,6822 \\
\hline $\begin{array}{l}\text { Abu jerami } \\
\text { tanpa } \\
\text { leaching } \\
\text { (AJTL) }\end{array}$ & 18,8012 & sda & 5,8772 & 31,2597 \\
\hline \multicolumn{5}{|c|}{ Randemen dari material mentah hingga UFAS } \\
\hline \multicolumn{4}{|c|}{$\begin{array}{l}\text { - UFAS yang berbahan baku sekam padi dengan leaching } \\
\text { (UFAS-SPL) }\end{array}$} & 5,0391 \\
\hline \multicolumn{4}{|c|}{$\begin{array}{l}\text { - UFAS yang berbahan baku sekam padi tanpa leaching (UFAS- } \\
\text { SPTL) }\end{array}$} & 4,4096 \\
\hline \multicolumn{4}{|c|}{$\begin{array}{l}\text { - UFAS yang berbahan baku jerami padi dengan leaching } \\
\text { (UFAS-JL) }\end{array}$} & 3,3708 \\
\hline \multicolumn{4}{|c|}{$\begin{array}{l}\text { - UFAS yang berbahan baku jerami padi tanpa leaching (UFAS- } \\
\text { JTL) }\end{array}$} & 3,4382 \\
\hline
\end{tabular}


Analisis XRD terhadap keempat UFAS yang dihasilkan dari penelitian ini menunjukkan bahwa pre-treatment leaching berpengaruh terhadap produk UFAS yang dihasilkan. Difraktogram pada Gambar 2 menunjukkan difraktogram UFAS-SPL melebar dengan puncak yang tumpul sedangkan difraktogram UFAS-SPTL memberikan puncak-puncak yang lebih lancip sehingga dapat dipahami bahwa bubuk halus UFAS-SPL lebih amorp dari UFAS-SPTL. Demikian pula halnya dengan UFAS-JL lebih amorp dari UFAS-JTL seperti yang ditunjukkan Gambar 3.

Identifikasi fase terhadap UFAS dari sekam padi (UFAS-SPL dan UFASSPTL) (lihat Tabel 2 di bawah) menunjukkan bahwa UFAS-SPTL mengandung fase utama silika dengan bentuk polimorfi kristobalit yang berwujud ploikristalin atau semi polikristalin dilihat dari puncak-puncak yang agak melebar dan tiga deretan puncak (metode Hanawalt menurut
$\mathrm{NIOSH}, 2003)$ dengan dua theta di kisaran 21-22 untuk puncak utama primer, $36-37^{\circ}$ untuk peak utama sekunder dan $31-32^{\circ}$ untuk puncak utama tersier. Hal ini juga tampak pada UFAS-SPL tetapi semua puncak melebar menjadi satu puncak besar, dimana semakin melebar puncak utama maka semakin amorp bubuk tersebut dan biasanya ukuran partikelnya semakin kecil. Sedangkan identifikasi fase terhadap UFAS dari jerami padi (UFAS-JL dan UFAS-JTL) menunjukkan bahwa puncak melebar pada difraktogram UFAS-JL menandakan bahwa bubuk UFAS-JL adalah amorp dan dengan identitas sangat mirip dengan difraktogram UFAS-SPL yaitu silika kristobalit. Namun, difraktogram UFAS-JTL terdiri dari banyak puncak yang agak lancip yang menunjukkan bahwa UFAS-JTL terdiri dari polikristalin silika yang fase beragam yaitu quarsa, kristobalit dan tridimit seperti yang ditunjukkan oleh Tabel 2 di bawah ini.

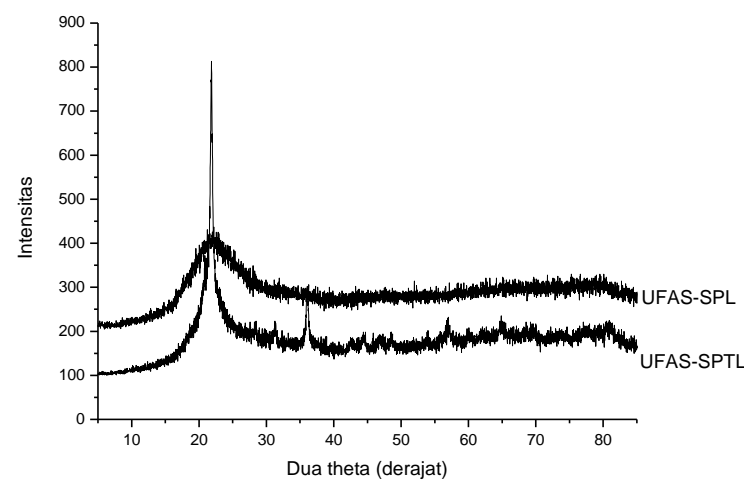

Gambar 2. Difraktogram dari UFAS-SPL dan UFAS-SPTL 


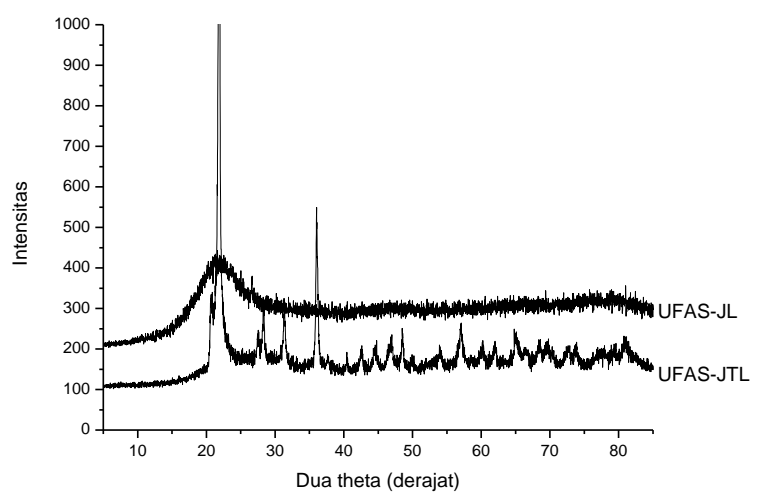

Gambar 3. Difraktogram dari UFAS-JL dan UFAS-JTL

Tabel 2. Identifikasi Fase Menggunakan Metode Hanawalt Terhadap Difraktogram UFAS-SPL, UFAS-SPTL, UFAS-JL dan UFAS-JTL.

\begin{tabular}{|c|c|c|c|c|c|}
\hline \multirow[t]{2}{*}{$\begin{array}{l}\text { Polimorfi } \\
\text { Silika }\end{array}$} & \multirow{2}{*}{$\begin{array}{l}\text { Tiga Puncak } \\
\text { Utama* } \\
\text { dengan dua } \\
\text { theta }\left(^{\circ}\right)\end{array}$} & \multicolumn{4}{|c|}{$\begin{array}{l}\text { Puncak-Puncak Bersesuaian** pada } \\
\text { Difraktogram dari: }\end{array}$} \\
\hline & & $\begin{array}{c}\text { UFAS- } \\
\text { SPL }\end{array}$ & $\begin{array}{l}\text { UFAS- } \\
\text { SPTL }\end{array}$ & UFAS-JL & UFAS-JTL \\
\hline \multirow{3}{*}{ kuarsa } & 26,66 & & & & $\sqrt{ }$ \\
\hline & 20,85 & & & & $\sqrt{ }$ \\
\hline & 50,16 & & & & $\sqrt{ }$ \\
\hline \multirow{3}{*}{ kristobalit } & 21,93 & $\sqrt{ }$ & $\sqrt{ }$ & $\sqrt{ }$ & $\sqrt{ }$ \\
\hline & 36,11 & $\sqrt{ }$ & $\sqrt{ }$ & $\sqrt{ }$ & $\sqrt{ }$ \\
\hline & 31,46 & $\sqrt{ }$ & $\sqrt{ }$ & $\sqrt{ }$ & $\sqrt{ }$ \\
\hline \multirow{3}{*}{ tridimit } & 21,62 & $\sqrt{ }$ & $\sqrt{ }$ & $\sqrt{ }$ & $\sqrt{ }$ \\
\hline & 20,50 & & & & \\
\hline & 23,28 & & & & \\
\hline
\end{tabular}

Keterangan: *Berurutan puncak utama primer, sekunder dan tersier menurut Metode Hanawalt menggunakan difraktogram yang dihasilkan dari XRD dengan radiasi $\mathrm{Cu}-\mathrm{K} \alpha-1$ (NIOSH, 2003); ** dua theta bersesuaian (puncak berdekatan) dan ditandai dengan tanda $\mathrm{V}$.

Berdasarkan Tabel 2 di atas, puncak primer utama dari difraktogram kristobalit muncul juga sebagai puncak utama difraktogram tridimit (dua theta berhimpitan) namun karena dua puncak utama lainnya (sekunder dan tersier) dari tridimit tidak muncul, maka dapat dipastikan bahwa difraktogram tersebut hanya terdiri dari fase kristobalit. Dengan demikian, keberadaan polimorfi silika kristobalit teridentifikasi dengan jelas pada keempat UFAS tersebut sebagai fase utama, namun polimorfi kuarsa muncul sebagai fase pendamping pada UFAS-JTL. 
Hasil analisis difraktogram XRF berupa kandungan unsur-unsur (dalam presentase relatif) dari abu sekam padi dan abu jerami dengan dan tanpa leaching dibandingkan, demikian juga hasil analisis XRF terhadap UFAS berbahan baku sekam dan jerami padi dengan dan tanpa leaching disajikan pada Tabel 3.

Tabel 3. Perbandingan kandungan unsur-unsur (\%) dalam abu sekam padi dan abu jerami dengan dan tanpa leaching serta UFAS yang dihasilkan

\begin{tabular}{|c|c|c|c|c|c|c|c|c|}
\hline \multirow{2}{*}{ Unsur } & \multicolumn{8}{|c|}{ Kandungan Oksida (\%) untuk: } \\
\hline & ASPL & ASPTL & AJL & $\overline{A J T L}$ & $\begin{array}{l}\text { UFAS- } \\
\text { SPL }\end{array}$ & $\begin{array}{l}\text { UFAS- } \\
\text { SPTL }\end{array}$ & $\begin{array}{l}\text { UFAS- } \\
\text { JL }\end{array}$ & $\begin{array}{l}\text { UFAS- } \\
\text { JTL }\end{array}$ \\
\hline $\mathrm{Si}$ & 97,400 & 85,300 & 93,000 & 62,200 & 98,800 & 95,500 & 98,500 & 83,600 \\
\hline $\mathrm{K}$ & 0,210 & 9,350 & 1,100 & 34,600 & (1) & 3,210 & 0,130 & 9,970 \\
\hline $\mathrm{Ca}$ & 1,650 & 1,660 & 5,000 & - & 0,708 & 0,640 & 0,862 & 4,000 \\
\hline $\mathrm{Cr}$ & 0,068 & 0,495 & 0,037 & 0,047 & 0,043 & 0,110 & 0,041 & 0,047 \\
\hline $\mathrm{Mn}$ & 0,060 & 0,380 & 0,072 & 0,770 & 0,046 & 0,100 & 0,091 & 1,000 \\
\hline $\mathrm{Fe}$ & 0,250 & 2,320 & 0,388 & 0,603 & 0,246 & 0,190 & 0,015 & 0,637 \\
\hline $\mathrm{Ni}$ & 0,030 & 0,240 & 0,020 & 0,087 & 0,020 & 0,036 & 0,024 & 0,030 \\
\hline $\mathrm{Cu}$ & 0,067 & 0,074 & 0,062 & 0,120 & 0,048 & 0,053 & 0,043 & 0,110 \\
\hline $\mathrm{Zn}$ & 0,040 & 0,053 & 0,110 & 0,092 & - & 0,009 & 0,067 & 0,130 \\
\hline $\mathrm{Eu}$ & 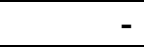 & - & 0,070 & 0,340 & - & 0,090 & - & 0,200 \\
\hline $\mathrm{Yb}$ & 0,040 & 0,020 & 0,030 & 0,080 & 0,050 & 0,050 & 0,020 & 0,030 \\
\hline $\mathrm{Re}$ & 0,015 & 0,040 & 0,090 & - & - & - & 0,040 & 0,100 \\
\hline $\mathrm{Ba}$ & - & - & - & 0,200 & - & - & - & 0,100 \\
\hline $\mathrm{Er}$ & - & - & - & - & - & - & - & - \\
\hline $\mathrm{S}$ & - & - & - & 0,560 & - & - & - & - \\
\hline $\mathrm{Ti}$ & - & - & - & 0,009 & - & - & 0,050 & 0,030 \\
\hline $\mathrm{Rb}$ & & - & & 0,210 & - & - & - & - \\
\hline
\end{tabular}

Berdasarkan data di atas, dapat dijelaskan tingkat kemurnian (dilihat dari presentasi Si) silika dalam bubuk abu yang dihasilkan pada pembakaran bubuk jerami dan bubuk sekam padi dengan dan tanpa leaching, abu sekam padi dengan leaching memiliki presentasi Si (demikian juga kalau dikonversi menjadi $\mathrm{SiO}_{2}$ ) jauh lebih tinggi daripada abu sekam padi tanpa pre-treatment leaching. Unsur-unsur logam yang terdeteksi berkurang $(\mathrm{K}, \mathrm{Cr}$, $\mathrm{Mn}, \mathrm{Fe}, \mathrm{Zn})$ menunjukkan bahwa persenyawaan-persenyawaan dari logam tersebut pada bubuk sekam padi dapat dipecah dan selanjutnya ion-ion logam tersebut dapat dilarutkan pada proses leaching yang menggunakan asam klorida encer berturut-turut $1 \mathrm{M}, 2$ $\mathrm{M}$ dan $3 \mathrm{M}$. Demikian pula halnya pada abu jerami yang terbuat dari bubuk jerami dengan dan tanpa leaching. Proses pengolahan abu sekam dan abu jerami selanjutnya yaitu proses pembuatan UFAS melalui refluks, pencucian dan pengeringan juga mampu menghasilkan tingkat kemurnian silika $\left(\mathrm{SiO}_{2}\right)$ yang lebih tinggi. Kalau dilihat dari tingkat kemurnian silika (dilihat Tabel 3 dari presentase relative 
Si) dan keamorpan fase silika (Gambar 2 dan 3) maka UFAS yang dihasilkan dari abu sekam padi dengan pretreatment leaching dan abu jerami dengan pre-treatment leaching, maka UFAS dapat dibuat dari kedua bahan baku tersebut, tetapi yang membedakan adalah randemen UFAS yang dihasilkan (lihat Tabel 1).

\section{SIMPULAN}

Perbandingan karakteristik bubuk silika (UFAS) yang dihasilkan dengan menggunakan bahan awal sekam dan jerami padi menyatakan bahwa bubuk amorp yang paling baik dengan kehomogenan fase yang dimiliki dapat dihasilkan dari sekam padi dengan pre-treatment leaching terlebih dulu. Metode ini juga dapat diterapkan pada bahan awal jerami karena menghasilkan karakter silika amorp yang relatif tidak berbeda namun dengan randemen yang lebih rendah. Studi karakterisasi lebih lanjut tentang karakter mikrostruktur (morfologi, topologi dan ukuran partikel) menggunakan SEM/TEM dan karakter ikatan Si-O dengan menggunakan spektroskopi IR perlu dilakukan terhadap keempat UFAS yang dihasilkan dari jerami dan sekam padi ini sehingga terungkap lebih rinci karakter keempat silika amorp tersebut.

\section{UCAPAN TERIMAKASIH}

$\begin{array}{cr}\text { Ucapan } & \text { terima } \\ \text { disampaikan } & \text { kepada }\end{array}$ Penelitian Universitas Pendidikan Ganesha atas dana penelitian DIPA tahun 2009 dengan kontrak nomor 193/H.48.14/PL/2009.

\section{DAFTAR PUSTAKA}

Balipost. 2003. Dulu Bahan Baku Pakan Ternak Kini Sekam Jadi Energi Hijau, 3 September 2003.

Conradt, R., P. Pimkhaokham and U. Leela- Adosorn. 1992. Nanostructured silica from rice husk, J. Non-Crystalline Solids, 145,75-79.

Gorthy, P. and M. Pudukotta G., 1999. Production of Silicon Carbide from Rice Husks, J. Am. Ceram. Soc., 82[6] 1393-1400.

Halimaton, H. 2007. Silica Aerogel, USPTO Patent Application 20070276051.

Karyasa, I W., and D. Walter. 2004. Xray Powder Diffraction Study on High Temperature Vacuum Sintered Silicon Carbide (SiC) Synthesized from Carbonized Rice Husk. PubScieAEIF. 9, 1-7.

Kim, K. S. and H. C. Choi, 1998. Characteristics of Adsorption of Rice-Hull Activated Carbon, Wat. Sci. Tech., 38[4-5].

NIOSH, 2003. Silica, Crystalline by XRD: Method 7500, in NIOSH Manual of Analytical Methods (NMAM), Fourth Edition, Issue 4, dated 15 March 2003 - Page 6 of 9.

Panpa, W., P. Sujaridworakul and S. Jinawath, 2005. Synthesis of ZSM-5 Zeolite from Rice Husk Ash. Proceeding of the First Workshop on the Utilization of Rice Husk and Rice Husk Silica, September 19, 2005. Chulalangkorn University Thailand.

Petrovskaya, T.S., Silicophosphate Glasses as a Component of Bioactive Coatings. Proceedings the 8th Russian-Korean International 
Symposium on Science and Technology, Volume 3, Issue , 26 June-3 July 2004 Page(s): 146 149.

Rahman, A. and F. L. Riley, 1989. The Control of Morphology in Silicon Nitride Powder prepared from Rice Husk, J. Eur. Ceram. Soc., 5, 11-22

Real, C., M. D. Alcala and J. M. Criado. 1996. Preparation of Silica from Rice Husks, J. Am. Ceram. Soc., 79[8], 2012-16.

Saiintawong, K., S. Wadal and $\mathrm{H}$. Jarunworaluck, 2005. Low Cost Process for Mullite Utilizing Industrial Waste as Starting Materials, Proceeding of the First Workshop on the Utilization of Rice Husk and Rice Husk Silica, September 19, 2005. Chulalangkorn University Thailand.

Schöneborn, M. 2008. Synthese und Kristallstrukturen polynärer Phosphateund Silicophosphate des
Titans. Dissertation, Rheinischen Friedrich-Wilhelms-Universität Bonn

Schmidt, H. K. 2001. Das Sol-Gel Verfahren, Chemie in Unserer Zeit, 3, 176-184.

Singh, S. K., B. C. Mohanty and S. Basu (2002) Bull. Mater. Sci., 25 (6), 561563.

Thundaij, N. and A.Nuntiya, 2008. Preparation of Nanosilica Powder from Rice Husk Ash by Precipitation Method, Chiang Mai J. Sci. 35(1): 206-211

Wada, S., W. Mosungnoen, K. Hemachandra and $\mathrm{H}$. Jarunworaluck. 2005. Survey of the Research on the Utilization of Rice Husk and Rice Husk Silica. Proceeding of the First Workshop on the Utilization of Rice Husk and Rice Husk Silica, September 19, 2005. Chulalangkorn University Thailand. 